UDC 66.012/66.092-977:661.722.3

\title{
CONTROL OF PROPANE PYROLYSIS PROCESS IN NONSTATIONARY CONDITIONS
}

\author{
A.M.Aliyev, A.R.Safarov, I.V.Balayev, I.I.Osmanova, A.M.Guseynova \\ M.Nagiyev Institute of Catalysis and Inorganic Chemistry, NAS of Azerbaijan
}

agil_s@mail.ru

Received 10.06.2019

Accepted 30.10.2019

\begin{abstract}
Calculation of propane pyrolysis proceeding in nonstationary conditions caused by coke deposition on the walls of the coil and leading to decrease of propylene productivity of the process has been given. For maintaining the productivity at a constant level the control function that takes into account the dependence of the propylene yield on time, reactor loading and pressure drop along the reactor due to coke formation has been proposed. Entering it into the mathematical model of the stationary process will allow stabilizing the process at any time during the operation of the furnace.
\end{abstract}

Keywords: pyrolysis, propane, nonstationary, control, coil diameter, pressure drop.

doi

\section{Introduction}

Propylene is the most important product of the petrochemical industry. The best raw material for its production is gaseous raw materials - propane and its mixtures, and the most common industrial method for its production is thermal pyrolysis of propane in the coil of a tube furnace at a temperature $(800-1000 \mathrm{~K})$, pressure (3-5 atm).

The study of the propane pyrolysis process at the "Ethylen-Polyethylene" Sumgait plant has been carried out according to the technique developed in [1]. There also have been developed its stoichiometric and mathematical models on the basis of kinetic, thermodynamic and hydrodynamic analyzes of processes occurring in the reactor [2].

In the process of propane dehydrogenation, in addition to the main ones, side reactions also occur, leading to the formation of secondary products, including coke. It is known, the gas velocity inside the reactor pipe is not the same. Near the pipe walls there is a membrane, or a layer that delays the flow of gas, and basically it is here that coke is formed. The thickness of the retaining layer is a function of the velocity of the gas stream. Therefore, the high gas mass velocities are used for minimizing the carbon deposition.

In addition, the small amounts of impurities (poisons) contained in the feed stream are adsorbed in the form of coke on the pipe sur- face. The poisonous molecule may also be a reactant or a product of the main reaction.

If coke begins to be deposited on the pipe walls, then in these places due to the bad thermal conductivity of the coke, the temperature of the pipe wall rises, the coke formation increases and, ultimately, the pipe wall burns out [3]. In addition, the coke deposition on the walls over time will reduce the diameter of the pipe that will change the hydrodynamic picture in the reactor. This will reduce the intensity of the process and lead to a decrease in the yield of propylene.

All it makes the process unsteady. To maintain the stable on propylene productivity, a control function should be entered into the mathematical model of the reactor which describes the process of propane pyrolysis under stationary conditions [2], taking into account the dependence of the propylene yield on time, load of raw materials and pressure drop in the reactor.

Taking into account the process of non-stationarity due to coke deposition

In [4-6], have been proposed the scheme and equation for the rate of coke formation during propane pyrolysis:

$$
\begin{aligned}
& \mathrm{C}_{3} \mathrm{H}_{8} \longrightarrow \text { Products } \\
& \mathrm{C}_{3} \mathrm{H}_{6} \stackrel{\mathrm{k}}{\longrightarrow} \text { Coke } \\
& r_{\mathrm{C}}=k \cdot \mathrm{C}_{\mathrm{C}_{3} \mathrm{H}_{6}}=k_{01} \exp \left(-\frac{E_{1}}{R T}\right) \cdot \mathrm{C}_{\mathrm{C}_{3} \mathrm{H}_{6}},
\end{aligned}
$$


where $k_{01}$ - pre-exponential factor of the reaction rate constant $k_{01}=5.82 \cdot 10^{14} ; E_{1}$ - activation energy equals to $73.58 \mathrm{kcal} / \mathrm{mole}$.

Increasing the thickness of coke deposition $\Delta t_{\mathrm{c}}$ over a time interval $\Delta \tau$ is:

$$
\Delta t_{\mathrm{c}}=\frac{r_{\mathrm{C}} \cdot \Delta \tau}{\rho_{\mathrm{C}}},
$$

where $\rho_{\mathrm{C}}-$ coke density, equals to $1600 \mathrm{~kg} / \mathrm{m}^{3}$.

In the case, if the amount of coke is very small compared to the amount of pyrolysis products, the coke formation rate can be considered constant over a certain time interval $\Delta \tau$, and the change of the pipe diameter as a result of coke deposition can be represented as [5]:

$$
\Delta d_{\text {in }}=d_{\text {in }}^{0}-d_{\text {in }}^{\mathrm{f}}=2 \Delta t_{\mathrm{c}},
$$

where $d_{\mathrm{in}}^{0}, d_{\mathrm{in}}^{\mathrm{f}}-$ initial and final pipe diameters.

Over the time, the thickness of the coke deposition is increased, that leads to an increasing in the pressure drop between the inlet and outlet of the reactor. And since at the exit from the industrial reactor the must be observed condition $P_{f} \mathrm{k} \geq 1.95$ (to overcome the resistance of the subsequent equipment), in order to maintain this limitation, it is necessary to increase the inlet pressure, and due to decrease in the yield of propylene as a result of coke deposition, gradually increase the load of propane. In the paper [6], data are presented (in \%) on the reduction in the diameter of an industrial propane cracking reactor due to coke deposition for 700 hours (1 month) of its operation, with a time period divided into intervals of 100 hours. Using these data, for every 100 hours we determine the values of decreasing the inner diameter $\Delta d_{\text {in }}$ and the values of the final diameters $d_{\text {in }}^{\mathrm{f}}$.

With the new values $d_{\text {in }}^{\mathrm{f}}$ obtained for every 100 hours according to the Darcy-Weisbach equation, we determine the pressure drops between the inlet and outlet of the reactor. The initial data for calculating the industrial reactor were:

- load of propane $g_{\mathrm{C}_{3} \mathrm{H}_{8}}^{0}=3200 \mathrm{~kg} / \mathrm{h}$;

- the length of straight pipe $L_{0}=11 \mathrm{~m}$;

- the length of all pipe $L=180 \mathrm{~m}$;
- inner diameter of a tube $d_{\mathrm{in}}=0.1322 \mathrm{~m}$;

- coefficient of friction $\lambda_{\mathrm{fr}}=0.013$;

- $\psi$ coefficient, taking into account the influence of the local resistances, $\psi=30$;

- total moles of components $\sum n_{i}=130.36 \mathrm{kmol} / \mathrm{h}$;

- reactor inlet pressure $P_{0}=4.2 \mathrm{~atm}$;

- reactor inlet temperature $T_{0}=826 \mathrm{~K}$.

Taking into account the dependence of $\mathrm{d}_{\text {in }}$ on time the Darcy-Weisbach equation instead of the one presented in [2] for the stationary model will take the form:

$$
\begin{aligned}
& \frac{\mathrm{d} P}{\mathrm{~d} l}=-0.50962 \cdot 10^{-13}\left(1+\frac{\psi d_{\text {in }}(\tau)}{L_{0}}\right) \times \\
& \times \lambda_{\text {тр }} \frac{\left(\sum n_{\mathrm{i}}\right) T}{P_{0} d_{\text {in }}{ }^{5}(\tau)} g_{\mathrm{C}_{3} \mathrm{H}_{8}}^{0},
\end{aligned}
$$

When calculating the process of propane pyrolysis under stationary conditions of its progress (without taking into account changes of the internal diameter due to coke deposition) with the same input parameters indicated above have been obtained optimum yield of propylene $g_{\mathrm{C}_{3} \mathrm{H}_{6}}=754.4 \mathrm{~kg} / \mathrm{h}$ with propane conversion equal to 0.236 [2].

Since over the time, as a result of coke deposition the pressure difference between the inlet and outlet of the reactor increases, that leads to a drop in the yield of propylene, to maintain the propylene productivity $(\approx 754.4$ $\mathrm{kg} / \mathrm{h}$ ), it is necessary to partially increase the propane load, with a view to preserving pressure at the outlet of the reactor $P_{f} \mathrm{k} \geq 1.95 \mathrm{~atm}$.

Table 1 for each time interval shows the corresponding input $\Delta P$ the modified values of the input pressures $P_{0}$ and increased loads $g_{\mathrm{C}_{3} \mathrm{H}_{8}}^{0}$ of reactor compared to their initial values. For these loads have been chosen approximate conversion values of $x$ so that the propylene yields were about $754 \mathrm{~kg} / \mathrm{h}$. In this case the final pressure in the reactor throughout the considered time interval (700 hour) satisfy the restriction $P_{f} \mathrm{k} \geq 1.95$ at. 
Table 1. Dynamics of parameters changes in the process in non-stationary conditions of its course

\begin{tabular}{|c|c|c|c|c|c|c|c|c|c|c|}
\hline \multirow{2}{*}{ 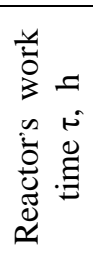 } & \multicolumn{2}{|c|}{$\begin{array}{l}\text { Reduction of in- } \\
\text { ner diameter } \Delta d_{\text {in }}\end{array}$} & \multirow{2}{*}{ 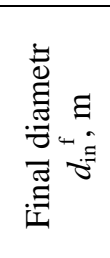 } & \multirow{2}{*}{ 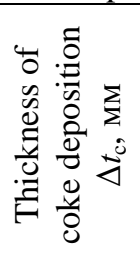 } & \multirow{2}{*}{ 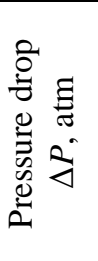 } & \multirow{2}{*}{ 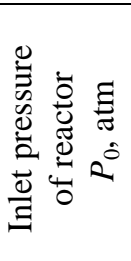 } & \multirow{2}{*}{ 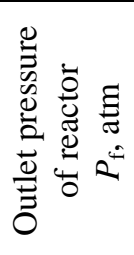 } & \multirow{2}{*}{ 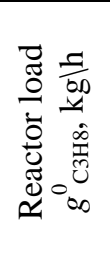 } & \multirow{2}{*}{$\begin{array}{l}\not{x} \\
\tilde{0} \\
\cdot \overline{0} \\
\overline{0} \\
己 \\
0 \\
0\end{array}$} & \multirow{2}{*}{ 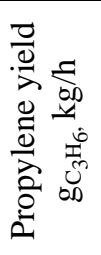 } \\
\hline & $\%$ & $\mathrm{~m}$ & & & & & & & & \\
\hline 100 & 3.31 & 0.00424 & 0.1280 & 2.12 & 1.3 & 4.204 & 2.900 & 3203.0 & 0.2354 & 754.0 \\
\hline 200 & 6.79 & 0.00898 & 0.1232 & 4.50 & 1.476 & 4.212 & 2.724 & 3209.0 & 0.2352 & 754.7 \\
\hline 300 & 9.64 & 0.01274 & 0.1195 & 6.40 & 1.663 & 4.234 & 2.537 & 3226.0 & 0.2339 & 754.6 \\
\hline 400 & 12.14 & 0.01605 & 0.1162 & 8.02 & 1.740 & 4.255 & 2.460 & 3242.0 & 0.2326 & 754.1 \\
\hline 500 & 15.36 & 0.02030 & 0.1119 & 10.20 & 2.095 & 4.272 & 2.105 & 3255.1 & 0.2320 & 755.2 \\
\hline 600 & 18.21 & 0.02410 & 0.1081 & 12.05 & 2.242 & 4.3017 & 1.958 & 3277.5 & 0.2300 & 753.8 \\
\hline 700 & 22.32 & 0.02950 & 0.1027 & 14.75 & 2.250 & 4.500 & 1.950 & 3399.5 & 0.2218 & 754.0 \\
\hline
\end{tabular}

\section{Process control in non-stationary conditions}

Since, at calculations making oriented by us, the values of propylene yields are rather approximate (Table 1), in order to precisely determine at any time how much it is necessary to increase the propane load and inlet pressure of the reactor for maintaining constant propylene productivity while observing the condition $P_{\mathrm{f}} \geq 1.95$ amt, we have been used the data in Table 1 and made a regression equation for the dependence of output $g_{\mathrm{C}_{3} \mathrm{H}_{6}}(Y)$ on control parameters: furnace operating time $\tau\left(X_{1}\right)$, reactor load $g_{\mathrm{C}_{3} \mathrm{H}_{8}}^{0}$ $\left(X_{2}\right)$ and pressure drop $\triangle P\left(X_{3}\right)$ in it:

$$
\begin{aligned}
& g_{\mathrm{C}_{3} \mathrm{H}_{6}}=\mathrm{A} \cdot \tau+\mathrm{B} \cdot g_{\mathrm{C}_{3} \mathrm{H}_{8}}^{0}+\mathrm{C} \cdot \Delta P \quad \text { or } \\
& Y=\mathrm{A} \cdot X_{1}+\mathrm{B} \cdot X_{2}+\mathrm{C} \cdot X_{3}
\end{aligned}
$$

The coefficients of the multiple regression equation (A, B, C) have been calculated by the least squares method by solving a system of normal linear equations on the basis of initial data [7]. Calculations to determine the coefficients have been performed using the Matlab software package [8]. The parametric identification of the regression model (5) led to the following form:

$Y_{\text {calc }}=-0.1932 \cdot X_{1}+0.2109 \cdot X_{2}+79.2088 \cdot X_{3}$.

After calculating the regression coefficients from the values of the independent variables for each experiment have been calculated the dependent variable $Y_{\text {calc }}$ - the so-called calculated values. A comparison of the values of the dependent variable $Y_{\exp }$ with the calculated values by the regression model (6) $Y_{\text {calc }}$ made it possible to estimate the relative errors of the obtained regression equation. The results are shown in Table 2.

Using the regression equation (6), we can control the process, i.e. to direct it towards maintaining the reactor productivity and the final pressure in it, despite the change in the conditions of its course over time due to coke deposition.

Table 2. The calculation results of propane pyrolysis process by using control function (6)

\begin{tabular}{|c|c|c|c|c|c|}
\hline$\tau$ & $g_{\mathrm{C}_{3} \mathrm{H}_{8}}^{0}$ & $\Delta P$ & $g_{\mathrm{C}_{3} \mathrm{H}_{6}}^{\exp }$ & $g_{\mathrm{C}_{3} \mathrm{H}_{6}}^{\text {calc }}$ & $\frac{\left(Y_{\text {exp }}-Y_{\text {calc }}^{(6)}\right.}{X_{\text {calc }}} \cdot 100 \%$ \\
\hline$X_{1}$ & $X_{2}$ & $X_{3}$ & $Y_{\exp }$ & 759.1641 & -0.6849 \\
\hline 100 & 3203.0 & 1.3 & 754.0 & 755.0503 & -0.04641 \\
\hline 200 & 3209.0 & 1.476 & 754.6 & 754.1276 & 0.062598 \\
\hline 300 & 3226.0 & 1.663 & 754.1 & 744.2811 & 1.302067 \\
\hline 500 & 3242.0 & 1.740 & 755.2 & 755.843 & -0.08515 \\
\hline 600 & 3255.1 & 2.095 & 753.8 & 752.8909 & 0.120605 \\
\hline 700 & 3277.5 & 2.242 & 754.0 & 759.9344 & -0.78705 \\
\hline
\end{tabular}


Replacing the hydrodynamic equation in the mathematical model of the propane pyrolysis process for stationary conditions [2] with equation (4) and adding the process control function (6), we obtain its non-stationary mathematical model.

The general concept of this model is as follows: after a certain time of operation of the furnace we determine by the regression equation (6) the amount of propane that must be fed into the reactor to maintain the given productivity on propylene $(754.4 \mathrm{~kg} / \mathrm{h})$; the new value of propane load together with other initial data are entered into the mathematical model by which is determined the propylene yield.

The figure shows the block-scheme of algorithm controlling the propane pyrolysis process taking into account the non-stationaryty of its course.

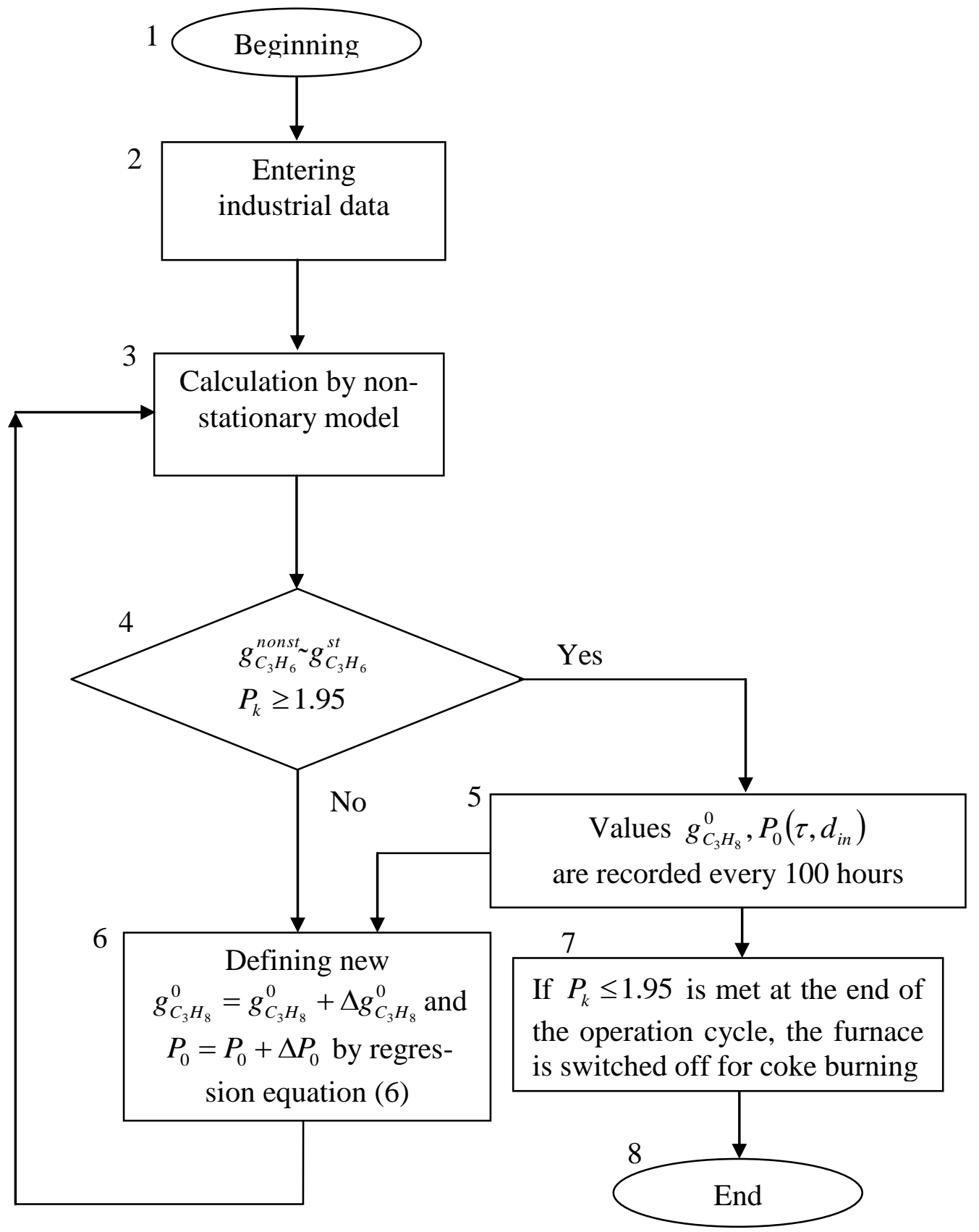

The block-scheme of algorithm controlling the propane pyrolysis process under non-stationary conditions. 
In block 3 the process is calculated using a non-stationary mathematical model and the value of the propylene output $g_{\mathrm{C}_{3} \mathrm{H}_{6}}^{\text {nonst }}$ is compared with the value of its productivity obtained under stationary conditions $g_{\mathrm{C}_{3} \mathrm{H}_{6}}^{\mathrm{st}}$ which we need to keep unchanged. Here the condition $P_{f} \geq 1.95 \mathrm{~atm}$ is checked. If these conditions are met, the values $g_{\mathrm{C}_{3} \mathrm{H}_{8}}^{0}$ and $\mathrm{P}_{0}$ are fixed for each time interval and are used in block 6 to go to the next interval. In block 6 according to the regression equation (6) are determined new values $g_{\mathrm{C}_{2} \mathrm{H}_{6}}^{0}$ and $P_{0}$. If at the end of the cycle of furnace operation (700 hours) the final pressure reaches the limit value of 1.95 atm (as can be seen from Table 1), then the furnace stops for coke burning.

Thus, at any moment of time by using the control function (6) we can determine how much it is necessary to increase the propane loading and pressure at the inlet of the reactor in order to keep the propylene productivity constant and not to violate the condition imposed on the final pressure.

\section{Conclusion}

Using the proposed function for controlling the process of propane pyrolysis under nonstationary conditions make it possible to main- tain the propylene yield and final pressure in the reactor at the desired level.

\section{References}

1. Aliyev A.M., Tairov A.Z., Quseynova A.M., Kalaushina Y.M., Shaxtaxtinskiy T.N. Primeneniye metodiki optimalnogo proyektirovaniya prosessov piroliza parafinovix uglevodorodov k prosesu piroliza propana. TOXT. 2004. T. 38. № 6. S. 693-698.

2. Aliyev A.M., Tairov A.Z., Quseynova A.M., Ismaylov N.R. Issledovaniye prosessa piroliza propane $s$ obratnoy svyazyu na osnove matematicheskoy modeli. Azerb. Chem. Journ. 2006. № 3. S. 15-26.

3. www.klmtechgroup.com/PDF/Articles/articles/AIC FT.pdf

4. Sandaram K.M., Froment G.F., Van Damme P.S. Coke deposition in the thermal cracking of ethane. AIChE J. 1981. V. 27. No 6. P. 946-951.

5. Meisong Yan. Simulation and optimization of an ethylene plant. A thesis in chemical engineering submitted to the Graduate Faculty of Texas Tech University in Partial Fulfillment of the Requirements for the Degree of Master of Science in chemical engineering. 2000. Texas. $114 \mathrm{p}$.

6. Astrid Yuliana Ramirez Hernandez. A model for the prediction of olefin production and coke deposition during thermal cracking of light hydrocarbons. Thesis presented as a requirement to obtain the degree of master of science Chemical Engineering. Universidad Nacional de Colombia. Medellin, Colombia. 2012. 53 p.

7. Balayev V.A., Məmmədov N.S. İdarəetmə obyektlərinin riyazi modellərinin alınması. Bakı: ADNA. 2010. $411 \mathrm{~s}$.

8. Anufriyev I.E., Smirnov A.B., Smirnova E.N. Matlab 7. SPb.: BXV-Peterburg. 2005. 1104 s.

\section{PROPANIN QEYRİ-STASIONAR ŞəRAITTINDə GEDON PIROLIZİ PROSESININ İDARӘEDILMəSI}

\section{A.M.əliyev, A.R.Səfərov, İ.V.Balayev, İ.í.Osmanova, A.M.Hüseynova}

Məqalədə piroliz sobalarının divarlarında əmələ gələn koksa görə qeyri-stasionar şəraitində gedən və bu səbəbdən propilenin məhsuldarlığının aşağı düşməsində propanın piroliz prosesinin hesablanması göstərilib. Məhsulldarlığı sabit səviyyədə saxlamaq üçün prosesin propilenin çıxımının yüklənməyə, vaxta və reaktor boyunca təzyiqin aşağı düß̧məsinin asılılığını nəzərə alaraq idarəetmə funksiyası təklif olunub. Bu funksiyanı prosesin riyazi modelinə daxil etməklə istəlinən vaxtda sobanın iş rejimini stabilləşdirilməsinə imkan verəcək.

Açar sözlor: piroliz, propan, qeyri-stasionarlıq, idarəetmə, borunun diametri, təzyiqin dü̈sməsi.

\section{УПРАВЛЕНИЕ ПРОЦЕССОМ ПИРОЛИЗА ПРОПАНА В НЕСТАЦИОНАРНЫХ УСЛОВИЯХ}

\section{А.М.Алиев, А.Р.Сафаров, И.В.Балаев, И.И.Османова, А.М.Гусейнова}

Приводится расчет процесса пиролиза пропана, протекающего в нестационарных условиях, вызванных отложениями кокса на стенках змеевика и приводящих к падению производительности пропилена. Для поддержания производительности на постоянном уровне предложена функция управления процессом, учитывающая зависимость выхода пропилена от времени, загрузки реактора и падения давления вдоль реактора из-за коксообразования. Введение её в математическую модель процесса позволит стабилизировать процесс в любой момент времени работы печи.

Ключевые слова: пиролиз, пропан, нестационарность, управление, диаметр пирозмеевика, падение давления. 